\title{
Malignancy Incidence, Management, and Prevention in Patients with Rheumatoid Arthritis
}

Katelynn M. Wilton · Eric L. Matteson

Received: April 3, 2017 / Published online: May 15, 2017

(C) The Author(s) 2017. This article is an open access publication

\begin{abstract}
Traditional and biologic disease-modifying antirheumatic drugs (DMARDs) are effective medications for the management of rheumatoid arthritis (RA). However, the effects of these medications on immune function raises concern that they may increase long-term cancer risk. The baseline risk for some cancers appears to differ in patients with RA compared to the general population, with the former having an increased risk of lymphoma, lung cancer and renal cancer, but a decreased risk of colorectal and breast cancer. Some DMARDs appear to increase the rate of specific cancer types (such as bladder cancer with cyclophosphamide), but
\end{abstract}

Enhanced content To view enhanced content for this article go to http://www.medengine.com/Redeem/3C18 F060322C0F80.

K. M. Wilton

Mayo Clinic Graduate School of Biomedical

Sciences, Mayo Clinic School of Medicine,

Rochester, MN, USA

E. L. Matteson $(\bowtie)$

Division of Rheumatology, Department of Health

Sciences Research, Mayo Clinic College of Medicine

and Science, Rochester, MN, USA

e-mail: matteson.eric@mayo.edu few appear to increase the overall cancer risk. Studying the link between lymphoma and disease severity in RA is complicated because patients with persistently active disease are at increased risk for lymphoma, and disease severity correlates with more intense use of immunosuppressive medications. Overall, cancer risk in patients with RA is slightly above that of the general population, with the increased risk likely secondary to an increased risk of lymphomas in those with high disease activity. Risk mitigation includes management of RA disease activity as well as age- and sex-appropriate cancer screening.

Keywords: Cancer; Comorbidity;

Inflammation; Malignancy; Rheumatoid arthritis

\section{INTRODUCTION}

Immunomodulatory therapies lessen the disease burden of rheumatoid arthritis (RA) and may affect the risk of malignancy developing in these patients. An improved understanding of the links between RA and its treatment is essential in developing prevention and management strategies for malignancy risk mitigation in RA patients.

This article is based on previously conducted studies and does not involve any new studies of 
human or animal subjects performed by either of the authors.

\section{MALIGNANCY RISK IN RA}

Knowledge of the baseline risk of malignancy in patients with RA is important in order to assess the potential effect of immunosuppressive therapies on this risk. Evaluation of the risk of these therapies is made difficult because both the disease and the treatments may be associated with an overall increased risk of malignancy, or at least an increased risk of some forms of malignancy, in these patients. Immunosuppressant and immunomodulatory medication use is almost ubiquitous in RA treatment regimens due to the realization that untreated RA has severe disabling and potentially life-threatening consequences that are substantially mitigated by the use of these medications.

The overall malignancy risk in patients with RA is similar to that of the general population, as shown in one recent meta-analysis that found only a modest (5-10\%) increase in overall malignancy in the former [1]. Similar trends have been reported in other studies [2-4]. The cancer risks of patients with presumed low [5] and high RA disease activity [6] have been reported to be similar to those of the general population. Overall cancer risk has been reported to be especially high in patients with severe forms of RA, such as Felty syndrome (RA with splenomegaly and neutropenia) [7].

The identification of risk factors for malignancy development can inform cancer prevention. In RA, cancer is associated with male sex $[8,9]$ and increased age $[9,10]$. Compared to the general population, however, the effect of RA on cancer risk is more pronounced in the younger age groups $[4,8,11]$. The highest cancer incidence in RA patients occurs in the first 5 years following RA diagnosis [4, 11], with decreasing risk over time [11]. Inflammation [12], often with increased white blood cell count [13], is associated with malignancy in RA.

\section{INCIDENCE OF SPECIFIC MALIGNANCIES IN RA PATIENTS}

\section{Breast Cancer}

Although breast cancer is common in female patients with RA [3], its occurrence appears to be lower than that in females in the general population $[1,8,14]$. The reason for this is unclear, although women with RA have also been reported to have a borderline decreased risk of developing breast cancer even before being diagnosed with RA diagnosis [15]. In spite of this general observation that women with RA have a lower risk of breast cancer, some sub-populations, including women under the age of 40 years [8] and non-Caucasian women [14], may be at increased risk. In addition, the prognosis of breast cancer in women with RA is worse than that in the general population $[16,17]$, with mortality increased by $40 \%$ [17]. Knowledge of this risk underscores the importance of breast cancer screening in women with RA, which should be completed in conformity with existing guidelines according to age and presence of other risk factors, such as family history.

\section{Cervical and Female Genital Cancers}

Rheumatoid arthritis-related disturbances of immune competence may hinder the clearance of pathogenic viruses, such as human papillomavirus (HPV). HPV persistence can transform cells and perpetuate cervical cancer [18], which usually progresses in stages, from HPV+ and abnormal pap smears to cervical intraepithelial neoplasia (CIN) and eventually to invasive cervical cancer in untreated women. Abnormal pap smears may be more common in women with RA than in the general population $[19,20]$, but they are also associated with traditional risk factors, such as birth control use and a diagnosis of previous sexually transmitted disease [21]. Although progression to pre-cancerous lesions (CIN) is accelerated in women with RA, studies of cervical cancer incidence have had mixed results [22, 23], and a meta-analysis [1] showed 
no consistent trend in cervical cancer risk. Women with RA should undergo age- and conventional risk factor-specific cervical cancer screening.

\section{Gastrointestinal Cancers}

The incidence of gastric cancer in patients with RA appears to be lower than that in the general population $[3,6]$, but the former who are diagnosed with gastric cancer have a worse prognosis [16]. Prevalence of liver cancer is similarly decreased [3], with a worse prognosis [16]. Liver cancer may be more prevalent in male and Hispanic patients [8].

The incidence of colon cancer in RA patients is decreased compared to that of the general population $[1,3,4]$, while the incidence of rectal cancer is less clear $[1,3]$. This trend in colon cancer has been attributed to increased non-steroidal anti-inflammatory drug (NSAID) use for pain and inflammation control in RA patients $[1,4,13]$. Within the general population, NSAIDs have been found to correlate with a $30 \%$ decrease in colorectal cancer risk, but have no effect on survival after diagnosis [24]. Although the effect of NSAID use on colon cancer incidence has not been directly studied in RA patients, there is likely a similar impact on colon cancer risk. Despite the decreased risk of colon cancer in patients with RA, for those diagnosed with colon cancer the prognosis is less favorable [16].

\section{Lung Cancer}

The incidence of lung cancer in patients with RA is generally reported to be increased compared to that in the general population $[1-3,25,26]$, especially in men [13], in those over 55 years of age, [26] and in those with Felty syndrome [7]. The risk of lung cancer in patients with RA prior to RA diagnosis is borderline decreased [15], despite a markedly increased risk shortly after RA diagnosis [15]. The survival prognosis for patients with RA who develop lung cancer is worse than that for the general population $[13,16]$. Smoking is a risk factor for lung cancer mortality, with mortality decreasing after smoking cessation [27].

\section{Lymphoproliferative Malignancies}

The risk of developing lymphoproliferative malignancies, including Hodgkin and nonHodgkin lymphoma (NHL), is increased in patients with RA [1-5, 11, 28, 29]. Patients with RA and NHL have an overall survival rate similar to that of patients in the general population with NHL, but lymphomas of the former are more likely to be low grade and mortality less likely to be lymphoma-related [30]. Risk factors for lymphoma in RA patients are similar to those in the general population, including male sex $[8,11,31]$ and increased age $[3,31]$. Hispanic patients with RA have an increased magnitude of lymphoma risk [8].

The percentage of Epstein-Barr virus (EBV)+ lymphoma cases is generally similar in the RA population to that in the general population [32-34], although one study did observe an increased prevalence of EBV+ lymphomas in RA patients [35]. Histologically, diffuse large B cell lymphoma (DLBCL) is the most frequent type of lymphoma in patients with RA, with an increased risk of between 50 and 200\% $[5,29,32]$. Compared to survival with other histological types, a diagnosis of DLBCL correlates with decreased survival [32, 35]. Most DLBCL is of the germinal center (GC) type $[28,36]$, but activated $\mathrm{B}$ cell (ABC) type has a worse prognosis [36] and is more likely to constitute disseminated disease [36]. All types of DLBCL are associated with RA disease activity $[34,36]$. In addition, clonality of the immunoglobulin heavy chain has been associated with decreased survival in patients with DLBCL [35].

Three theories have been proposed in attempts to explain increased lymphoma risk in RA patients. The first is that a common genetic predisposition links RA and lymphoma [15]. This is unlikely, as first-degree relatives [37] and patients before RA diagnosis [15] do not have an increased risk of lymphoma. The second theory is that lymphomas arise in RA due to iatrogenic immunosuppression, allowing immunogenic 
tumors to develop. However, the increasing use of immunosuppressants is not correlated with an increased or decreased lymphoma rate in RA patients; i.e. the lymphoma rate in these patients has remained unchanged $[15,29,33,37]$, and the risk of lymphomas before the widespread use of aggressive immunosuppressants (1965-1984) remains comparable to risk today [32]. Immunosuppressant use is widely believed to be a confounding factor in malignancy development, as the disease activity and severity RA largely correlates with immunosuppressant use.

The development of lymphoma in patients with RA is most likely due to the underlying RA disease pathobiology. Up to the seventh decile of RA disease activity, there is a minimal increased risk of lymphoma, but those in the top $20 \%$ of disease activity have a markedly heightened risk of lymphoma [34]. Physicians should be watchful for lymphoma development in patients with RA who have high cumulative disease activity, or a Disease Activity Score-28 for Rheumatoid Arthritis of $>5.7$ [34]. While immunosuppressive treatment itself may cause some lymphomas, better control of disease activity appears to negate this increased risk [33]. This potential double-edged sword underscores the need for optimal, but not overzealous immunosuppression in the treatment of RA.

The risk of multiple myeloma in patients with RA is about the same as in the general population. The authors of one meta-analysis commented that although there is serious heterogeneity among studies, the highest quality studies do not reflect an increased risk of multiple myeloma in RA patients [38].

\section{Skin Cancers}

The effect of RA on development of skin cancer incidence is unclear. The largest study to date noted no increased risk of melanoma in biologic-naïve patients with RA [39], although other studies have shown mixed results $[1,8,40]$. The risk of non-melanoma skin cancer (NMSC) has been reported to be both increased [41] and decreased [11] in RA patients, and the prognosis for squamous cell carcinoma may be worse [16]. The development of NMSC may be associated with the use of certain immunosuppressive medications, including tumor necrosis factor (TNF) inhibitors [41-44] and methotrexate [45].

\section{Other Cancers}

The incidence of prostate cancer is probably not increased in men with RA, although study results are mixed [1]. Men with RA who develop prostate cancer appear to have a decreased time to mortality and a 50\% increased mortality [17]. Renal cell carcinoma has been reported in patients with RA and may confer an increased mortality, but it is not clear if risk is actually increased [13].

\section{TRADITIONAL DISEASE-MODIFYING ANTIRHEUMATIC DRUGS: THERAPEUTICS AND CANCER RISK}

Immunosuppressive medications effectively control RA symptoms. Iatrogenic cancer risk is of major concern in RA, but assessment of this risk is confounded by lack of comparable control groups, as risk assessments from the general population, or even patients with less severe RA, can misinform risks. Because the great majority of patients with RA have received some type of therapy during their disease course, cancer risk studies on traditional disease-modifying antirheumatic drugs (DMARDs) generally compare malignancy risk in this patient population to that of the general population, or the risk of cancer in RA patients receiving agents not associated with increased risk, such as hydroxychloroquine or sulfasalazine [46-48]. In addition, disparate results have emerged from randomized controlled trials (RCTs) and population-based cohort studies, largely due to differences in populations and biases. In particular, many early RCTs enroll patients with severe disease that is not effectively controlled by medications. These patients, though randomized, are followed for relatively short periods of time, allowing minimal ascertainment of long-term risk. In population-based cohort studies, medication usage is not random, and 
certain medications are favored for patients with more severe disease. Although follow-up is usually longer and results more representative of the broad range in RA activity (from mild to severe disease), confounders cannot be entirely accounted for.

\section{Azathioprine}

Azathioprine may increase the risk of lymphoproliferative and a number of other malignancies in patients with RA $[25,49,50]$. Since this medication is usually reserved for patients with severe disease, these findings are likely to be confounded by disease severity [40].

\section{Cyclophosphamide}

Cyclophosphamide is usually reserved for severe extra-articular manifestations of RA [40], especially vasculitis and scleritis. This medication increases the risk of a number of malignancies, including hematologic malignancies [50] and urinary tract and bladder cancer [51, 52]. The authors of one study noted that bladder cancer occurred in $25 \%$ of patients receiving a cumulative dose of $>80 \mathrm{~g}$ cyclophosphamide. This observation, as well as the declining incidence of severe extraarticular disease with overall improved disease management in recent decades, has led to this medication being used less frequency and then often and primarily for shorter durations in cases of life- or organ-threatening disease [51]. Hydration and mesna use can be implemented to attempt to decrease these risks [51].

\section{Glucocorticoids}

Tapered doses of glucocorticoids are very effective in controlling inflammatory activity, but also confer considerable side effects. It has been reported that the use of glucocorticoids is associated with an increased incidence of malignancy in RA patients $[2,10]$. A study of veterans with RA showed glucocorticoid use to be a risk factor for NMSC [53]. However, all of these studies are confounded by RA disease activity.
Overall, glucocorticoids do not increase malignancy risk.

Generally, glucocorticoid use appears to decrease lymphoma risk [28, 34, 42, 54], consistently among different disease severities [54]. Oral glucocorticoid use of $<2$ years has no impact on lymphoma risk, whereas longer glucocorticoid treatment regimens may decrease lymphoma risk [54]. Steroid treatment does not alter clinical presentation or time course of lymphoma [54].

\section{Leflunomide}

Although few studies have been conducted to assess the effect of leflunomide on cancer risk in RA patients, in vitro studies have shown that, like azathioprine, methotrexate and cyclophosphamide, leflunomide may have some anti-neoplastic activity against multiple cancer types [55-58]. One recent study found a threefold increased risk of pancreatic cancer in patients with RA treated with leflunomide. This result was not reproduced in an analysis of patients from the UK and Sweden, although the datasets did show a trend toward an increased risk [59].

\section{Methotrexate}

Methotrexate may have no effect on [2] or may increase $[43,45]$ cancer risk, specifically melanoma, NHL and lung cancer [45]. Reports of its effect on the development of lymphoproliferative disease are mixed. Some hematologic malignancies (between 27 [60] and 90\% [61]) spontaneously regress between 2 and 5 months [35, 61-63] after methotrexate withdrawal in patients with RA [35, 60-64]. Results from population-based studies suggest that methotrexate does not increase the incidence of lymphoproliferative cancers over the baseline incidence in RA patients $[9,28,49,63,64]$. In one study the incidence of lymphomas in patients with RA with or without methotrexate was similar, except that lymphomas developed sooner in those receiving methotrexate and some patients regressed upon methotrexate withdrawal [60]. Although methotrexate seems 
to contribute to the growth of some lymphomas, it does not appear to increase their overall incidence [35].

Methotrexate may have divergent effects on lymphoma development, decreasing the development of some lymphomas via decreased RA-related immunologic activity (which is linked to lymphoma development [34, 42]) and promoting other lymphomas through immunosuppression [63], leading to an overall null impact on incidence. Methotrexate-induced lymphomas likely represent a small minority of lymphomas in RA patients $[49,63]$.

The majority of lymphoma cases are DLBCL, although diverse histologic patterns have been observed [35, 61-64]. DLBCL is associated with a worse prognosis and is less likely to regress with methotrexate withdrawal [35]. Lymphoma-specific survival was found not to differ based on methotrexate usage, but prognosis was worse than for lymphoma in the general population [60].

Lymphoma treatment in the setting of RA with methotrexate use is complicated. Survival is similar among patients in whom methotrexate is withdrawn and those receiving chemotherapy [64]. The authors of some studies advise watchful waiting up to 3 months after methotrexate withdrawal before starting the patient on chemotherapy, especially if the lymphoma is associated with EBV positivity and monoclonality [61, 63]. Methotrexate withdrawal is preferred to immediate chemotherapy when there is a good prognosis, single lesion and low risk of fast progression-but not in young patients with a high serum lactate dehydrogenase levels and poor risk status [64]. Lymphocyte recovery 2 weeks after methotrexate withdrawal has shown promising preliminary results as a predictor of response [61]. After cancer remission, glucocorticoid therapy and/or DMARD therapy with sulfasalazine and hydroxychloroquine are the preferred RA treatments if possible [64] as the impact of restarting methotrexate on subsequent lymphoma development is uncertain [61]. It is not clear which of the biologic and small molecule inhibitor medications may be preferred in patients with refractory disease, although TNF inhibitors are generally avoided.

\section{Rituximab}

Rituximab is a B cell-depleting antibody against CD20 that has not been reported to affect malignancy risk in RA patients [65]. Rituximab has also been effectively used in the treatment of B-cell lymphomas in patients with RA [66], serving as a single intervention to help control RA disease activity and prevent lymphoma growth and development [62].

\section{TNF Inhibitors}

Tumor necrosis factor alpha (TNF- $\alpha$ ) facilitates both tumor cell death and cancer-promoting inflammation [67]. Despite immense interest, an answer to the question of what precisely is the effect of TNF inhibitors on cancer risk in RA patients has been illusive due to the rarity of cancer events [68].

There are five Federal Drug Administration-approved TNF- $\alpha$ inhibitors available in the USA-three monoclonal antibodies (adalimumab, golimumab and infliximab), a pegylated Fab fragment (certolizumab) and a soluble receptor fusion protein (etanercept). Although the results of early RCTs on TNF inhibitors suggested a dose-dependent increase in overall cancer $[69,70]$, more recent diverse studies, including both population-based and prospective studies, have failed to confirm this result $[2,57,71-78]$. It is possible that this difference is the result of an increased disease severity in patients enrolled in the RCTs compared to the general population or that it is secondary to biased prescribing; i.e. patients with a high cancer risk may forgo TNF inhibitors, thus biasing population-based studies. Patients with RA taking TNF inhibitors and DMARDs have a similar cancer stage at diagnosis [79] and a similar mortality rate [71] and malignancy recurrence rate [12]. There do not appear to be major differences in individual TNF inhibitors in terms of cancer risk [80].

Individual cancer types vary in incidence, with some data suggesting an increase in NMSC in RA patients taking TNF- $\alpha$ inhibitors $[43,44,73,74]$. Although several studies have 
also suggested an increase in melanoma with TNF- $\alpha$ inhibitors $[43,44,76]$, the largest study to date, involving 48,304 patients with RA taking TNF inhibitors from 11 European biologics registrars, noted no increased risk, with an incident rate ratio of 1.1 (95\% confidence interval 0.8-1.6) compared to biologic-naïve patients [39]. A few studies have noted other variations in cancer risk, including an increased risk in colon cancer in RA patients taking TNF inhibitors $[68,81]$ compared to patients with RA not taking TNF inhibitors, but the risk overall is similar to that in the general population. Ovarian cancer is possibly increased [81], while risk of female breast cancer has been reported to be decreased [72]. One recent retrospective study observed that patients with RA treated with etanercept had a decreased cancer risk, but the results may have been subject to channeling bias and some bias secondary to study exclusion criteria [57].

Although a number of studies have reported a positive correlation between TNF inhibitor use and lymphoma in RA $[9,68,75]$, the majority of studies have failed to reproduce that association [31, 43, 67, 76]. Confounding factors, specifically RA disease activity, might be responsible for the results of these positive studies. Since TNF inhibitors are normally given to patients with moderate to severe RA [31], and increased disease activity has been shown to strongly correlate with lymphoma risk [34, 42], it is possible that populations of patients chosen to receive TNF inhibitors for their RA might have an apparently increased lymphoma risk secondary to their disease activity and not due to these medications [68].

The majority of studies have detected an increased risk of NMSC [41-44] and possibly melanoma [42, 43, 76, 82] with TNF inhibitor treatment in RA patients, but others have reported no difference in risk with TNF inhibitors. On balance it would appear that melanoma risk is not increased with their use [72, 81, 83]. Male [82] and Caucasian [83] patients with RA on TNF inhibitors may be at the greatest risk for these skin cancers; consequently, these patients should undergo regular screening for skin cancer $[44,83]$.

\section{Other Biologics and Small Molecule Inhibitors}

Cancer risk information for these therapeutics is scarce. Tocilizumab, an antibody against the interleukin-6 cytokine receptor, has not been associated with an increased risk for overall malignancy $[84,85]$. Tofactinib, a small molecule Janus kinase inhibitor $[86,87]$, and abatacept, a fusion immunologlobulin targeting CTLA-4 [1, 78, 88], have not been associated with increased malignancy risk, but these medications have not been used in as many patients or for as long as some of the TNF inhibitors.

\section{CANCER OUTCOMES}

Patients with RA have worse cancer mortality $[13,89]$ and prognosis $[16,17,25,89]$ and may be more likely to have metastatic disease [17]. Worse survival is seen for hematopoetic malignancies [25], squamous cell carcinoma [16], upper aerodigestive tract cancers [13, 16, 25], gastrointestinal cancers [16] and liver [16] prostate [17] and breast cancer [16, 17] when diagnosed in the setting of RA. RA diagnosis appears to have more of an impact on mortality in lower stage cancer, with little impact on stage 4 cancers [89] (Table 1).

\section{PATIENTS WITH PREVIOUS CANCERS}

Studies evaluating previous cancer diagnosis in RA are scarce. The majority of these are specific to TNF inhibitors and caution against their use in patients with previous malignancy [90] for 5-10 ten years after malignancy diagnosis [91]. Female patients with RA in remission from breast cancer have been reported to have an equal recurrence rate regardless of TNF inhibitor usage [91, 92] or methotrexate use, although the use of thiopurines correlated with an increased recurrence rate [92]. A similar finding was observed for patients with head and neck [93], cervical [94], or overall cancer in remission [90], with the possible exception of melanoma 
Table 1 Risk status for specific cancer types in patients with rheumatoid arthritis

\begin{tabular}{|c|c|c|c|c|}
\hline Cancer type & $\begin{array}{l}\text { Risk in general } \\
\text { rheumatoid } \\
\text { arthritis }\end{array}$ & Prognosis & $\begin{array}{l}\text { Impact of } \\
\text { therapeutics }\end{array}$ & Recommendations [95] \\
\hline Overall & $10 \%$ increase $[1]$ & $\begin{array}{l}\text { Worse } \\
\qquad[13,16,17,25,89]\end{array}$ & & Follow national guidelines \\
\hline Breast & $\begin{array}{l}\text { Decreased } \\
\quad[1,8,14]\end{array}$ & Worse $[16,17]$ & $\begin{array}{l}\text { Decreased with } \\
\text { TNFi [72] }\end{array}$ & $\begin{array}{l}45-55 \text { years of age: Annual } \\
\text { mammography } \\
>55 \text { years of age: annual or } \\
\text { biannual mammography }\end{array}$ \\
\hline Cervical & $\begin{array}{l}\text { Likely unchanged } \\
\text { [1] }\end{array}$ & & & $\begin{array}{l}\text { 21-29 years of age : Pap smear } \\
\text { every } 3 \text { years } \\
30-65 \text { years of age: Pap smear } \\
\text { and HPV test every } 5 \text { years, or } \\
\text { Pap smear every } 3 \text { years }\end{array}$ \\
\hline Gastric & Decreased $[3,6]$ & Worse [16] & & \\
\hline Liver & Decreased [3] & Worse [16] & & \\
\hline Colon & Decreased $[1,3,4]$ & Worse [16] & $\begin{array}{l}\text { NSAIDs may } \\
\text { inhibit } \\
\text { tumorigenesis } \\
{[24]} \\
\text { TNFi may restore } \\
\text { general } \\
\text { population level } \\
\text { risk }[68,81]\end{array}$ & $\begin{array}{l}\text { Annual (gFOBT or FIT) or } \\
\text { triannual (Multitarget Stool } \\
\text { DNA test) stool testing or } \\
\text { flexible signmoidoscopy every } \\
5 \text { years } \\
\text { Colonoscopy every } 10 \text { years or } \\
\text { after any positive tests }\end{array}$ \\
\hline Lung & $\begin{array}{l}\text { Increased } \\
\qquad[1-3,25,26]\end{array}$ & Worse $[13,16,25]$ & $\begin{array}{l}\text { May be increased } \\
\text { with MTX [45] }\end{array}$ & $\begin{array}{l}\text { Smoking cessation counseling, as } \\
\text { appropriate } \\
\text { Consideration of pulmonary } \\
\text { imaging risks and benefits }\end{array}$ \\
\hline Lymphoproliferative & $\begin{array}{l}\text { Increased }(2 \times) \\
\quad[1-5,11,28,29]\end{array}$ & Worse [25] & $\begin{array}{l}\text { Increased with } \\
\text { Aza, CYC [50] } \\
\text { Maybe prevented } \\
\text { with diligent } \\
\text { glucocorticoid } \\
\text { use [54] } \\
\text { Potential to treat } \\
\text { B cell } \\
\text { lymphomas with } \\
\text { RTX }[62,66]\end{array}$ & $\begin{array}{l}\text { Control ofrheumatoid arthritis } \\
\text { disease activity is important }\end{array}$ \\
\hline
\end{tabular}


Table 1 continued

\begin{tabular}{|c|c|c|c|c|}
\hline Cancer type & $\begin{array}{l}\text { Risk in general } \\
\text { rheumatoid } \\
\text { arthritis }\end{array}$ & Prognosis & $\begin{array}{l}\text { Impact of } \\
\text { therapeutics }\end{array}$ & Recommendations [95] \\
\hline Multiple myeloma & $\begin{array}{l}\text { Likely unchanged } \\
\text { [38] }\end{array}$ & & & \\
\hline $\begin{array}{l}\text { Non-melanoma } \\
\text { skin cancer }\end{array}$ & $\begin{array}{l}\text { Likely unchanged } \\
\qquad[11,41]\end{array}$ & Worse for SCC [16] & $\begin{array}{l}\text { May be increased } \\
\text { with TNFi } \\
{[43,44,73,74]}\end{array}$ & $\begin{array}{l}\text { Potential for skin cancer } \\
\text { screening, depending on risk } \\
\text { factors }\end{array}$ \\
\hline Melanoma & $\begin{array}{l}\text { Likely unchanged } \\
\text { [39] }\end{array}$ & & $\begin{array}{l}\text { Maybe increased } \\
\text { with MTX [45] }\end{array}$ & \\
\hline Prostate & $\begin{array}{l}\text { Likely unchanged } \\
\text { [1] }\end{array}$ & Worse [17] & & $\begin{array}{l}\text { Informed decision about } \\
\text { prostate-specific antigen } \\
\text { screening in men }\end{array}$ \\
\hline $\begin{array}{l}\text { Renal cell } \\
\text { carcinoma }\end{array}$ & Unclear [13] & Worse [13] & & \\
\hline
\end{tabular}

$A z$ a Azathioprine, CYC cyclophosphamide, FIT fecal immunochemical test, HPV human papillomavirus, gFOBT guaiac-based fecal occult blood test, MTX methotrexate, NSAIDs non-steroidal anti-inflammatory drugs, $R T X$ rituximab, SCC squamous cell carcinoma, TNFi tumor necrosis factor inhibitor

[90]. Overall, the use of DMARDs, both biologic and conventional, in patients with RA in cancer remission is understudied. There does not appear to be a significantly increased risk of cancer recurrence in patients on biological therapy.

\section{CURRENT STATE OF CANCER MANAGEMENT AND SCREENING IN RA}

In patients with RA without a previous cancer diagnosis, additional screening beyond the nationally recommended guidelines is not required prior to start of systemic therapy [77]. In all patients with RA, usual age- and sex-appropriate cancer screening should be pursued, possibly with more frequent screening for skin cancer (Table 1). In general, national guidelines (recently reviewed in [95]) are appropriate for patients with RA. In the USA, mammograms are recommended in female patients over 45 years of age for early breast cancer detection. Pap smears and human pappillomavirus vaccination should be used as preventive measures for cervical cancer in female patients aged between 21 and 65 years. The risks and benefits of prostate cancer screening should be considered in men independent of their RA status. Colon cancer screening, including annual or triannual stool tests and colonoscopy every 10 years, is an appropriate therapeutic strategy for patients with RA. Unlike in the general population, in patients with RA, control of RA disease activity via immunosuppressive agents may decrease cancer risk, and thus RA disease activity should be well controlled. To date, no studies have specifically looked at the risks and benefits of increased skin cancer screening in patients with RA, but such screening may be a reasonable addition, especially in individuals with otherwise an increased skin cancer risk. Although the use of chest X-ray to detect lung cancer has not been studied in patients with RA, chest X-rays may be valuable for some patients with an especially high risk for lung cancer, specifically those with a significant smoking history $(>30$ pack-years). Smoking cessation should be a primary objective in these cases. 
Regarding DMARD use in patients with a cancer diagnosis, the 2015 American College of Rheumatology guidelines [96] provide some guidance for specific medication usage in patients with pre-existent cancer. In the case of previous solid malignancy, the use of conventional DMARDs is preferred over biologics, but supportive evidence for these recommendations is weak. In the case of previous lymphoproliferative malignancy, rituximab or a combination of conventional DMARDs with abatacept or tocilizumab is preferred over TNF inhibitors. The role of rituximab as a dual agent to both control RA disease activity and lymphoma progression has been suggested and may be an optimal therapeutic in some cases $[62,66]$.

\section{CONCLUSIONS}

Malignancy is a major comorbidity in patients with RA and is related both to the disease and its treatment. Patients with RA appear to be at an increased risk of lung cancer and lymphoma, while the risk of colorectal and breast cancer is lower. Control of the underlying disease is critical to reducing cancer risk in RA patients. Vigilant cancer screening according to age- and sex-specific guidelines is important in RA management.

\section{ACKNOWLEDGMENTS}

Katelynn M. Wilton was supported by the National Institutes of General Medical Sciences (Grant T32-GM-65841) and the Mayo Clinic College of Medicine's Medical Scientist Training Program. The content is solely the responsibility of the authors and does not necessarily represent the official views of the National Institutes of Health. No sponsorship was received for this study or publication of this article.

All named authors meet the International Committee of Medical Journal Editors (ICMJE) criteria for authorship for this manuscript, take responsibility for the integrity of the work as a whole, and have given final approval to the version to be published.
Disclosures. Katelynn M. Wilton has no conflicts of interest to disclose. Eric L. Matteson has received research grants from Mesoblast Inc., Pfizer, UCB Pharma, Novartis, Jansen, Celgene, Genentech/Roch and Ardea Biosciences.

Compliance with Ethics Guidelines. This article is based on previously conducted studies and does not involve any new studies of human or animal subjects performed by either of the authors.

Open Access. This article is distributed under the terms of the Creative Commons Attribution-NonCommercial 4.0 International License (http://creativecommons.org/licenses/ by-nc/4.0/), which permits any noncommercial use, distribution, and reproduction in any medium, provided you give appropriate credit to the original author(s) and the source, provide a link to the Creative Commons license, and indicate if changes were made.

\section{REFERENCES}

1. Simon TA, Thompson A, Gandhi KK, Hochberg MC, Suissa S. Incidence of malignancy in adult patients with rheumatoid arthritis: a meta-analysis. Arthritis Res Ther. 2015;15(17):212.

2. Raheel S, Crowson CS, Wright K, Matteson EL. Risk of malignant neoplasm in patients with incident rheumatoid arthritis 1980-2007 in relation to a comparator cohort: a population-based study. Int J Rheumatol. 2016;2016:4609486.

3. Hashimoto A, Chiba N, Tsuno H, Komiya A, Furukawa $H$, Matsui $T$, et al. Incidence of malignancy and the risk of lymphoma in Japanese patients with rheumatoid arthritis compared to the general population. J Rheumatol. 2015;42(4):564-71.

4. Huang WK, Chiou MJ, Kuo CF, Lin YC, Yu KH, See LC. No overall increased risk of cancer in patients with rheumatoid arthritis: a nationwide dynamic cohort study in Taiwan. Rheumatol Int. 2014;34(10):1379-86.

5. Andersen CL, Lindegaard H, Vestergaard H, Siersma VD, Hasselbalch HC, de Fine Olivarius N, et al. Risk of lymphoma and solid cancer among patients with 
rheumatoid arthritis in a primary care setting. PLoS ONE. 2014;9(6):e99388.

6. Gridley G, McLaughlin JK, Ekbom A, Klareskog L, Adami HO, Hacker DG, et al. Incidence of cancer among patients with rheumatoid arthritis. J Natl Cancer Inst. 1993;85(4):307-11.

7. Gridley G, Klippel JH, Hoover RN, Fraumeni JF Jr. Incidence of cancer among men with the Felty syndrome. Ann Intern Med. 1994;120(1):35-9.

8. Parikh-Patel A, White RH, Allen M, Cress R. Risk of cancer among rheumatoid arthritis patients in California. Cancer Causes Control. 2009;20(6):1001-10.

9. Wolfe F, Michaud K. Lymphoma in rheumatoid arthritis: the effect of methotrexate and anti-tumor necrosis factor therapy in 18,572 patients. Arthritis Rheum. 2004;50:1740-51.

10. Carmona L, Abasolo L, Descalzo MA, Perez-Zafrilla B, Sellas A, de Abajo F, et al. Cancer in patients with rheumatic diseases exposed to TNF antagonists. Semin Arthritis Rheum. 2011;41(1):71-80.

11. Chen YJ, Chang YT, Wang CB, Wu CY. The risk of cancer in patients with rheumatoid arthritis: a nationwide cohort study in Taiwan. Arthritis Rheum. 2011;63(2):352-8.

12. Strangfeld A, Hierse F, Rau R, Burmester GR, Krummel-Lorenz B, Demary W, et al. Risk of incident or recurrent malignancies among patients with rheumatoid arthritis exposed to biologic therapy in the German biologics register RABBIT. Arthritis Res Ther. 2010;12(1):R5.

13. Abasolo L, Judez E, Descalzo MA, Gonzalez-Alvaro I, Jover JA, Carmona L. Cancer in rheumatoid arthritis: occurrence, mortality, and associated factors in a South European population. Semin Arthritis Rheum. 2008;37(6):388-97.

14. Tian G, Liang JN, Wang ZY, Zhou D. Breast cancer risk in rheumatoid arthritis: an update meta-analysis. Biomed Res Int. 2014;2014:453012.

15. Hellgren K, Smedby KE, Feltelius N, Baecklund E, Askling J. Do rheumatoid arthritis and lymphoma share risk factors?: a comparison of lymphoma and cancer risks before and after diagnosis of rheumatoid arthritis. Arthritis Rheum. 2010;62(5):1252-8.

16. Ji J, Liu X, Sundquist K, Sundquist J. Survival of cancer in patients with rheumatoid arthritis: a follow-up study in Sweden of patients hospitalized with rheumatoid arthritis 1 year before diagnosis of cancer. Rheumatology (Oxford). 2011;50(8): 1513-8.
17. Nayak P, Luo R, Elting L, Zhao H, Suarez-Almazor ME. Impact of rheumatoid arthritis on the mortality of elderly patients who develop cancer: a population-based study. Arthritis Care Res (Hoboken). 2017;69(1):75-83.

18. Kim SC, Schneeweiss S, Liu J, Karlson EW, Katz JN, Feldman S, et al. Biologic disease-modifying antirheumatic drugs and risk of high-grade cervical dysplasia and cervical cancer in rheumatoid arthritis: a cohort study. Arthritis Rheumatol. 2016;68(9):2106-13.

19. Raposo A, Tani C, Costa J, Mosca M. Human papillomavirus infection and cervical lesions in rheumatic diseases: a systematic review. Acta Reumatol Port. 2016;41(3):184-90.

20. Mercado U. Abnormal cervicovaginal cytology in women with rheumatoid arthritis. Ginecol Obstet Mex. 2010;78(2):94-8.

21. Gillet VG, Solomon DH, Shadick NA, Weinblatt $\mathrm{ME}$, Iannaccone CK, Feldman S, et al. Behavioral and clinical factors associated with self-reported abnormal Papanicolaou tests in rheumatoid arthritis. J Womens Health (Larchmt). 2014;23(9):771-6.

22. Wadstrom H, Frisell T, Sparen P, Askling J. Do RA or TNF inhibitors increase the risk of cervical neoplasia or of recurrence of previous neoplasia? A nationwide study from Sweden. Ann Rheum Dis. 2016;75(7):1272-8.

23. Kim SC, Glynn RJ, Giovannucci E, Hernandez-Diaz S, Liu J, Feldman S, et al. Risk of high-grade cervical dysplasia and cervical cancer in women with systemic inflammatory diseases: a population-based cohort study. Ann Rheum Dis. 2015;74(7):1360-7.

24. Din FV, Theodoratou E, Farrington SM, Tenesa A, Barnetson RA, Cetnarskyj R, et al. Effect of aspirin and NSAIDs on risk and survival from colorectal cancer. Gut. 2010;59(12):1670-9.

25. Thomas E, Symmons DP, Brewster DH, Black RJ, Macfarlane GJ. National study of cause-specific mortality in rheumatoid arthritis, juvenile chronic arthritis, and other rheumatic conditions: a 20 year followup study. J Rheumatol. 2003;30(5):958-65.

26. Khurana R, Wolf R, Berney S, Caldito G, Hayat S, Berney SM. Risk of development of lung cancer is increased in patients with rheumatoid arthritis: a large case control study in US veterans. J Rheumatol. 2008;35(9):1704-8.

27. Joseph RM, Movahedi M, Dixon WG, Symmons DP. Smoking-related mortality in patients with early rheumatoid arthritis: a retrospective cohort study using the clinical practice research datalink. 
Arthritis Care Res (Hoboken). 2016;68(11):1598-606.

28. Baecklund E, Smedby KE, Sutton LA, Askling J, Rosenquist R. Lymphoma development in patients with autoimmune and inflammatory disorderswhat are the driving forces? Semin Cancer Biol. 2014;24:61-70.

29. Hellgren K, Baecklund E, Backlin C, Sundstrom C, Smedby KE, Askling J. Rheumatoid arthritis and risk of malignant lymphoma-is the risk still increased? Arthritis Rheumatol. 2017;69(4):700-08.

30. Mikuls TR, Endo JO, Puumala SE, Aoun PA, Black NA, O'Dell JR, et al. Prospective study of survival outcomes in non-Hodgkin's lymphoma patients with rheumatoid arthritis. J Clin Oncol. 2006;24(10):1597-602.

31. Askling J, Baecklund E, Granath F, Geborek P, Fored M, Backlin C, et al. Anti-tumour necrosis factor therapy in rheumatoid arthritis and risk of malignant lymphomas: relative risks and time trends in the Swedish Biologics Register. Ann Rheum Dis. 2009;68(5):648-53.

32. Baecklund E, Sundstrom C, Ekbom A, Catrina AI, Biberfeld P, Feltelius N, et al. Lymphoma subtypes in patients with rheumatoid arthritis: increased proportion of diffuse large B cell lymphoma. Arthritis Rheum. 2003;48(6):1543-50.

33. Baecklund E, Askling J, Rosenquist R, Ekbom A, Klareskog L. Rheumatoid arthritis and malignant lymphomas. Curr Opin Rheumatol. 2004;16(3):254-61.

34. Baecklund E, Iliadou A, Askling J, Ekbom A, Backlin C, Granath F, et al. Association of chronic inflammation, not its treatment, with increased lymphoma risk in rheumatoid arthritis. Arthritis Rheum. 2006;54 (3):692-701.

35. Ichikawa A, Arakawa F, Kiyasu J, Sato K, Miyoshi H, Niino D, et al. Methotrexate/iatrogenic lymphoproliferative disorders in rheumatoid arthritis: histology, Epstein-Barr virus, and clonality are important predictors of disease progression and regression. Eur J Haematol. 2013;91(1):20-8.

36. Baecklund E, Backlin C, Iliadou A, Granath F, Ekbom A, Amini RM, et al. Characteristics of diffuse large B cell lymphomas in rheumatoid arthritis. Arthritis Rheum. 2006;54(12):3774-81.

37. Ekstrom $\mathrm{K}$, Hjalgrim $\mathrm{H}$, Brandt L, Baecklund $\mathrm{E}$, Klareskog L, Ekbom A, et al. Risk of malignant lymphomas in patients with rheumatoid arthritis and in their first-degree relatives. Arthritis Rheum. 2003;48(4):963-70.
38. Shen K, Xu G, Wu Q, Zhou D, Li J. Risk of multiple myeloma in rheumatoid arthritis: a meta-analysis of case-control and cohort studies. PLOS ONE. 2014;9(3):e91461.

39. Mercer LK, Askling J, Raaschou P, Dixon WG, Dreyer L, Hetland ML, et al. Risk of invasive melanoma in patients with rheumatoid arthritis treated with biologics: results from a collaborative project of 11 European Biologic Registers. Ann Rheum Dis. 2017;76(2):386-91.

40. Mercer LK, Davies R, Galloway JB, Low A, Lunt M, Dixon WG, et al. Risk of cancer in patients receiving non-biologic disease-modifying therapy for rheumatoid arthritis compared with the UK general population. Rheumatology (Oxford). 2013;52(1):91-8.

41. Chakravarty EF, Michaud K, Wolfe F. Skin cancer, rheumatoid arthritis, and tumor necrosis factor inhibitors. J Rheumatol. 2005;32(11):2130-5.

42. Baecklund E, Ekbom A, Sparen P, Feltelius N, Klareskog L. Disease activity and risk of lymphoma in patients with rheumatoid arthritis: nested case-control study. BMJ. 1998;317(7152):180-1.

43. Mariette X, Matucci-Cerinic M, Pavelka K, Taylor P, van Vollenhoven R, Heatley R, et al. Malignancies associated with tumour necrosis factor inhibitors in registries and prospective observational studies: a systematic review and meta-analysis. Ann Rheum Dis. 2011;70(11):1895-904.

44. Askling J, Fahrbach K, Nordstrom B, Ross S, Schmid $\mathrm{CH}$, Symmons D. Cancer risk with tumor necrosis factor alpha (TNF) inhibitors: meta-analysis of randomized controlled trials of adalimumab, etanercept, and infliximab using patient level data. Pharmacoepidemiol Drug Saf. 2011;20(2):119-30.

45. Buchbinder R, Barber M, Heuzenroeder L, Wluka AE, Giles G, Hall S, et al. Incidence of melanoma and other malignancies among rheumatoid arthritis patients treated with methotrexate. Arthritis Rheum. 2008;59(6):794-9.

46. Geborek P, Bladstrom A, Turesson C, Gulfe A, Petersson IF, Saxne T, et al. Tumour necrosis factor blockers do not increase overall tumour risk in patients with rheumatoid arthritis, but may be associated with an increased risk of lymphomas. Ann Rheum Dis. 2005;64(5):699-703.

47. Naldi L. Malignancy concerns with psoriasis treatments using phototherapy, methotrexate, cyclosporin, and biologics: facts and controversies. Clin Dermatol. 2010;28(1):88-92.

48. Engels EA, Pfeiffer RM, Fraumeni JF, et al. Spectrum of cancer risk among us solid organ transplant recipients. JAMA. 2011;306(17):1891-901. 
49. Williams CA, Bloch DA, Sibley J, Haga M, Wolfe F, Raynauld JP, et al. Lymphoma and luekemia in rheumatoid arthritis: are they associated with azathioprine, cyclophosphamide, or methotrexate? J Clin Rheumatol. 1996;2(2):64-72.

50. Bernatsky S, Clarke AE, Suissa S. Hematologic malignant neoplasms after drug exposure in rheumatoid arthritis. Arch Intern Med. 2008;168(4):378-81.

51. Radis CD, Kahl LE, Baker GL, Wasko MC, Cash JM, Gallatin A, et al. Effects of cyclophosphamide on the development of malignancy and on long-term survival of patients with rheumatoid arthritis. A 20-year followup study. Arthritis Rheum. 1995;38(8):1120-7.

52. Asten P, Barrett J, Symmons D. Risk of developing certain malignancies is related to duration of immunosuppressive drug exposure in patients with rheumatic diseases. J Rheumatol. 1999;26(8):1705-14.

53. Amari W, Zeringue AL, McDonald JR, Caplan L, Eisen SA, Ranganathan P. Risk of non-melanoma skin cancer in a national cohort of veterans with rheumatoid arthritis. Rheumatology (Oxford). 2011;50(8):1431-9.

54. Hellgren K, Iliadou A, Rosenquist R, Feltelius N, Backlin C, Enblad G, et al. Rheumatoid arthritis, treatment with corticosteroids and risk of malignant lymphomas: results from a case-control study. Ann Rheum Dis. 2010;69(4):654-9.

55. Alhefdhi A, Burke JF, Redlich A, Kunnimalaiyaan M, Chen H. Leflunomide suppresses growth in human medullary thyroid cancer cells. J Surg Res. 2013;185(1):212-6.

56. Baumann P, Mandl-Weber S, Volkl A, Adam C, Bumeder I, Oduncu F, et al. Dihydroorotate dehydrogenase inhibitor A771726 (leflunomide) induces apoptosis and diminishes proliferation of multiple myeloma cells. Mol Cancer Ther. 2009;8(2):366-75.

57. Lan JL, Tseng $\mathrm{CH}$, Chen JH, Cheng CF, Liang WM, Tsay GJ. Reduced risk of all-cancer and solid cancer in Taiwanese patients with rheumatoid arthritis treated with etanercept, a TNF-alpha inhibitor. Medicine (Baltimore). 2017;96(7):e6055.

58. Zhu S, Yan X, Xiang Z, Ding HF, Cui H. Leflunomide reduces proliferation and induces apoptosis in neuroblastoma cells in vitro and in vivo. PLoS ONE. 2013;8(8):e71555.

59. Strangfeld A, Hyrich K, Askling J, Arkema E, Davies R, Listing J, et al. Detection and evaluation of a drug safety signal concerning pancreatic cancer: lessons from a joint approach of three European biologics registers. Rheumatology (Oxford). 2011;50(1):146-51.

60. Hoshida Y, Xu JX, Fujita S, Nakamichi I, Ikeda J, Tomita Y, et al. Lymphoproliferative disorders in rheumatoid arthritis: clinicopathological analysis of 76 cases in relation to methotrexate medication. J Rheumatol. 2007;34(2):322-31.

61. Inui $\mathrm{Y}$, Matsuoka $\mathrm{H}$, Yakushijin $\mathrm{K}$, Okamura $\mathrm{A}$, Shimada T, Yano S, et al. Methotrexate-associated lymphoproliferative disorders: management by watchful waiting and observation of early lymphocyte recovery after methotrexate withdrawal. Leuk Lymphoma. 2015;56(11):3045-51.

62. Niitsu N, Okamoto $M$, Nakamine $H$, Hirano $M$. Clinicopathologic correlations of diffuse large B-cell lymphoma in rheumatoid arthritis patients treated with methotrexate. Cancer Sci. 2010;101(5):1309-13.

63. Mariette X, Cazals-Hatem D, Warszawki J, Liote F, Balandraud N, Sibilia J. Lymphomas in rheumatoid arthritis patients treated with methotrexate: a 3year prospective study in France. Blood. 2002;99(11):3909-15.

64. Kameda T, Dobashi H, Miyatake N, Inoo M, Onishi $\mathrm{I}$, Kurata N, et al. Association of higher methotrexate dose with lymphoproliferative disease onset in rheumatoid arthritis patients. Arthritis Care Res (Hoboken). 2014;66(9):1302-9.

65. Aaltonen KJ, Joensuu JT, Virkki L, Sokka T, Aronen $\mathrm{P}$, Relas $\mathrm{H}$, et al. Rates of serious infections and malignancies among patients with rheumatoid arthritis receiving either tumor necrosis factor inhibitor or rituximab therapy. J Rheumatol. 2015;42(3):372-8.

66. Kawano N, Ono N, Yoshida S, Kuriyama T, Yamashita K, Beppu K, et al. Successful treatment of immunodeficiency-associated EBV-negative lymphoproliferative disorders in rheumatoid arthritis by methotrexate withdrawal and prevention of its relapse by rituximab administration. J Clin Exp Hematop. 2012;52(3):193-8.

67. Lebrec $\mathrm{H}$, Ponce $\mathrm{R}$, Preston BD, Iles J, Born TL, Hooper M. Tumor necrosis factor, tumor necrosis factor inhibition, and cancer risk. Curr Med Res Opin. 2015;31(3):557-74.

68. Askling J, Fored CM, Baecklund E, Brandt L, Backlin C, Ekbom A, et al. Haematopoietic malignancies in rheumatoid arthritis: lymphoma risk and characteristics after exposure to tumour necrosis factor antagonists. Ann Rheum Dis. 2005;64(10):1414-20.

69. Bongartz T, Sutton AJ, Sweeting MJ, Buchan I, Matteson EL, Montori V. Anti-TNF antibody 
therapy in rheumatoid arthritis and the risk of serious infections and malignancies: systematic review and meta-analysis of rare harmful effects in randomized controlled trials. JAMA. 2006;295:2275-85.

70. Bongartz T, Warren FC, Mines D, Matteson EL, Abrams KR, Sutton AJ. Etanercept therapy in rheumatoid arthritis and the risk of malignancies: a systematic review and individual patient data meta-analysis of randomised controlled trials. Ann Rheum Dis. 2009;68(7):1177-83.

71. Mercer LK, Lunt M, Low AL, Dixon WG, Watson $\mathrm{KD}$, Symmons DP, et al. Risk of solid cancer in patients exposed to anti-tumour necrosis factor therapy: results from the British Society for Rheumatology Biologics Register for Rheumatoid Arthritis. Ann Rheum Dis. 2015;74(6):1087-93.

72. Buchbinder R, Van Doornum S, Staples M, Lassere M, March L. Malignancy risk in Australian rheumatoid arthritis patients treated with anti-tumour necrosis factor therapy: analysis of the Australian Rheumatology Association Database (ARAD) prospective cohort study. BMC Musculoskelet Disord. $2015 ; 20(16): 309$.

73. Damjanov N, Nurmohamed MT, Szekanecz Z. Biologics, cardiovascular effects and cancer. BMC Med. 2014;18(12):48.

74. Morgan CL, Emery P, Porter D, Reynolds A, Young A, Boyd $\mathrm{H}$, et al. Treatment of rheumatoid arthritis with etanercept with reference to disease-modifying anti-rheumatic drugs: long-term safety and survival using prospective, observational data. Rheumatology (Oxford). 2014;53(1):186-94.

75. Nanau RM, Neuman MG. Safety of anti-tumor necrosis factor therapies in arthritis patients. J Pharm Pharm Sci. 2014;17(3):324-61.

76. Ramiro S, Gaujoux-Viala C, Nam JL, Smolen JS, Buch M, Gossec L, et al. Safety of synthetic and biological DMARDs: a systematic literature review informing the 2013 update of the EULAR recommendations for management of rheumatoid arthritis. Ann Rheum Dis. 2014;73(3):529-35.

77. Roubille C, Richer V, Starnino T, McCourt C, McFarlane A, Fleming P, et al. Evidence-based recommendations for the management of comorbidities in rheumatoid arthritis, psoriasis, and psoriatic arthritis: expert opinion of the Canadian dermatology-rheumatology comorbidity initiative. J Rheumatol. 2015;42(10):1767-80.

78. Solomon DH, Kremer JM, Fisher M, Curtis JR, Furer $\mathrm{V}$, Harrold LR, et al. Comparative cancer risk associated with methotrexate, other non-biologic and biologic disease-modifying anti-rheumatic drugs. Semin Arthritis Rheum. 2014;43(4):489-97.

79. Raaschou P, Simard JF, Neovius M, Askling J. Does cancer that occurs during or after anti-tumor necrosis factor therapy have a worse prognosis? A national assessment of overall and site-specific cancer survival in rheumatoid arthritis patients treated with biologic agents. Arthritis Rheum. 2011;63(7):1812-22.

80. Michaud TL, Rho YH, Shamliyan T, Kuntz KM, Choi HK. The comparative safety of tumor necrosis factor inhibitors in rheumatoid arthritis: a meta-analysis update of 44 trials. Am J Med. 2014;127(12):1208-32.

81. Dreyer L, Mellemkjaer L, Andersen AR, Bennett P, Poulsen UE, Juulsgaard Ellingsen T, et al. Incidences of overall and site specific cancers in TNFalpha inhibitor treated patients with rheumatoid arthritis and other arthritides-a follow-up study from the DANBIO Registry. Ann Rheum Dis. 2013;72(1): $79-82$.

82. Raaschou P, Simard JF, Holmqvist M, Askling J. Rheumatoid arthritis, anti-tumour necrosis factor therapy, and risk of malignant melanoma: nationwide population based prospective cohort study from Sweden. BMJ. 2013;08(346):f1939.

83. Mercer LK, Green AC, Galloway JB, Davies R, Lunt M, Dixon WG, et al. The influence of anti-TNF therapy upon incidence of keratinocyte skin cancer in patients with rheumatoid arthritis: longitudinal results from the British Society for Rheumatology Biologics Register. Ann Rheum Dis. 2012;71(6):869-74.

84. Yamamoto K, Goto H, Hirao K, Nakajima A, Origasa $\mathrm{H}$, Tanaka $\mathrm{K}$, et al. Longterm Safety of Tocilizumab: results from 3 years of followup postmarketing surveillance of 5573 patients with rheumatoid arthritis in Japan. J Rheumatol. 2015;42(8):1368-75.

85. Schiff $\mathrm{MH}$, Kremer JM, Jahreis A, Vernon E, Isaacs JD, van Vollenhoven RF. Integrated safety in tocilizumab clinical trials. Arthritis Res Ther. 2011;13(5):R141.

86. Curtis JR, Lee EB, Kaplan IV, Kwok K, Geier J, Benda $B$, et al. Tofacitinib, an oral Janus kinase inhibitor: analysis of malignancies across the rheumatoid arthritis clinical development programme. Ann Rheum Dis. 2016;75(5):831-41.

87. Winthrop KL. The emerging safety profile of JAK inhibitors in rheumatic disease. Nat Rev Rheumatol. $2017 ; 13: 234-243$.

88. Simon TA, Smitten AL, Franklin J, Askling J, Lacaille $D$, Wolfe $F$, et al. Malignancies in the rheumatoid arthritis abatacept clinical development 
programme: an epidemiological assessment. Ann Rheum Dis. 2009;68(12):1819-26.

89. Simard JF, Ekberg S, Johansson AL, Askling J. What is the impact of chronic systemic inflammation such as rheumatoid arthritis on mortality following cancer? Ann Rheum Dis. 2016;75(5):862-6.

90. Dixon WG, Watson KD, Lunt M, Mercer LK, Hyrich $\mathrm{KL}$, Symmons DP. Influence of anti-tumor necrosis factor therapy on cancer incidence in patients with rheumatoid arthritis who have had a prior malignancy: results from the British Society for Rheumatology Biologics Register. Arthritis Care Res (Hoboken). 2010;62(6):755-63.

91. Raaschou P, Frisell T, Askling J. TNF inhibitor therapy and risk of breast cancer recurrence in patients with rheumatoid arthritis: a nationwide cohort study. Ann Rheum Dis. 2015;74(12):2137-43.

92. Mamtani R, Clark AS, Scott FI, Brensinger CM, Boursi B, Chen L, et al. Association between breast cancer recurrence and immunosuppression in rheumatoid arthritis and inflammatory bowel disease: a cohort study. Arthritis Rheumatol. 2016;68(10):2403-11.
93. Phillips C, Zeringue AL, McDonald JR, Eisen SA, Ranganathan P. Tumor necrosis factor inhibition and head and neck cancer recurrence and death in rheumatoid arthritis. PLoS ONE. 2015;10(11): e0143286.

94. Mercer LK, Low AS, Galloway JB, Watson KD, Lunt $\mathrm{M}$, Symmons DP, et al. Anti-TNF therapy in women with rheumatoid arthritis with a history of carcinoma in situ of the cervix. Ann Rheum Dis. 2013;72(1):143-4.

95. Smith RA, Andrews $\mathrm{K}$, Brooks D, DeSantis CE, Fedewa SA, Lortet-Tieulent J, et al. Cancer screening in the United States, 2016: a review of current American Cancer Society guidelines and current issues in cancer screening. CA Cancer J Clin. 2016;66(2):96-114.

96. Singh JA, Saag KG, Bridges SL Jr, Akl EA, Bannuru RR, Sullivan MC, et al. 2015 American College of Rheumatology guideline for the treatment of rheumatoid arthritis. Arthritis Care Res (Hoboken). 2016;68(1):1-25. 